\title{
1. The concept of sustainability and its application in international trade, investment and finance
}

\author{
Clair Gammage and Tonia Novitz
}

\section{INTRODUCTION}

In May 2017, the contributors to this book met at the University of Oslo under the auspices of a project titled 'Sustainable Market Actors for Responsible Trade' (SMART) funded by the European Commission. While the other aspects of this project, led by Professor Beate Sjåfjell, were engaged in analysis of corporate structures and conduct, as well as supply chain activities, our task was to identify the international legal architecture which enabled but also constrained the European Union (EU) as a legal and policy actor in the sphere of trade, investment and finance. This book reflects our discussions at that date and the input of all those attending.

What emerged from the debates we engaged in from 2017-18 in Oslo, but also in other places such as Bristol, Brussels and Heidelberg, was the significance of 'sustainability' as a transformational idea. It is the prelude to each chapter and, for that reason, is reviewed here in our Introduction in terms of its contested definition and reach. In so doing, we reflect on whether the Sustainable Development Goals (SDGs) appended to the United Nations (UN) Resolution on the 2030 Agenda offer scope to bring together the divergent strands of past international instruments on 'sustainability' or 'sustainable development', and explore the potential for future policy coherence. We do not underestimate the significance of what appears to be the emergence of a global consensus on the importance of these issues. However, it shall become apparent that we also detect certain implicit tensions between the economic, social, environmental and even cultural strands of sustainability brought together in the SDGs, as well as outstanding questions relating to their status in law and policy. We believe that our role should be to expose rather than cloak uncertainties and potential conflicts, for this is more likely to lead to their genuine clarification and resolution. 
An understanding of sustainability and its contours shapes each of the chapters in this edited collection. So, too, does the appreciation of the authors of the stark limitations placed on realization of SDGs by the international legal frameworks that govern trade, investment and finance. In this context, our contributors examine a range of issues arising from the actions of the EU as a trade actor, the rules and mechanisms in place within the World Trade Organization (WTO), as well as provisions operationalized through free trade agreements (FTAs) for the achievement of sustainability objectives. The specific rules of investment arbitration, as established by the International Centre of Investment Disputes (ICSID) within the World Bank, but also other arbitration systems, such as the United Nations Commission on International Trade Law (UNCITRAL) and the structures established by the Swedish Chamber of Commerce, further become of interest here. Our authors, in this respect, identify different potential opportunities for crafting the terms of investment agreements and their interpretation and application. In so doing, they identify potential space within these structures for the consideration of sustainability alongside commercial objectives. In addition, we are interested in the intersections between public international law and private forms of legal regulation, concerning for example the conduct of commercial supply chains, corporate governance and financial (including tax) regulation.

This volume identifies four potential obstacles to policy coherence around sustainable development. The first is the diverse forms of governance that operate at international, regional and national levels. We attend to accusations that pluralism has led to normative fragmentation that detracts from combined and reinforcing legal and policy frameworks. The second is the scope for access to justice, which remains questionable in a variety of contexts. One is the standard supply chain situation where a worker or consumer is distanced from the corporate entity causing harm. Others include the dispute mechanisms used in trade and investment agreements, which allow for minimal recourse to human rights or other social or environmental values. A third concern is the difficulty of discerning the designated, actual and appropriate roles of different actors that create and enforce legal and regulatory norms in this sphere. We have an interest here in the EU and the United States (US) as state actors that wield particular influence, but the actions of all states are relevant for our purposes. The scope for innovative regulatory solutions that promote a greater role for private actors (eg, corporate due diligence) or create hybrid actors (in the context of blended finance) and the difficulties associated with the careful demarcation of their competence will be pertinent here. This observation leads to the identification of a fourth potential impediment to Policy Coherence for Development (PCD) and sustainability objectives, which is the problem of accountability. Transparency (including the timing of release of information) 
and inclusion in decision-making and supervisory processes become important in this setting.

\section{A BRIEF HISTORY OF SUSTAINABILITY AS A CONTESTED CONCEPT ON THE INTERNATIONAL STAGE}

In this part of our Introduction, we explore the notion that sustainability is a contested concept. We trace its histories, establishing that despite the frequent early attempts to equate sustainability with solely environmental concerns, this concept has economic, social and even cultural dimensions which are gradually gaining recognition. Moreover, while 'development' and the alleviation of poverty are vital to sustainability in the sense of the durability of policies, 'sustainability' has a broader currency which, in its current international incarnation, can be understood to encompass various human rights protections alongside broader policy objectives, and which can be applicable in the Global North as well as the Global South. ${ }^{1}$

The first articulation of 'sustainable development' is found in the World Conservation Strategy of 1980, where the concept was broadly defined as a relating to 'humanity's relationship with the biosphere'. ${ }^{2}$ For development to be sustainable, the World Conservation Strategy proposed that 'it must take account of social and ecological factors, as well as economic ones; of the living and non-living resource base; and of the long term as well as the short-term

\footnotetext{
1 We are using these terms in preference to standard distinctions between so-called 'developing' and 'developed' countries, which we consider problematic and also potentially insulting to lower-income countries. We do, however, also accept that certain legal texts require reference to standards of 'development' such as Part IV of the General Agreement on Tariffs and Trade (GATT), which refers to 'less-developed contracting parties'. On balance, however, while a neat dividing line between the Global North and South is also highly dubious, we see this as the 'least worst' alternative as a frame for our debates, as long as nuanced attention is paid to the differences between countries in each of these 'blocs' and to the dynamics of different emerging and declining economies. Contributors to this volume have made their own choices on terminology and use the terms 'developing countries' and 'Global South' as they consider appropriate. See Naur Dados and Raewyn Connell, 'The Global South' (2012) 11(1) Contexts 12-13 available at https://kups.ub.uni-koeln.de/6399/1/voices012015_concepts_of the global_south.pdf, last accessed 22 November 2018; and also 'Concepts of the Global South - Voices from around the world', Global South Studies Center, University of Cologne, Germany (2015) at http://gssc.uni-koeln.de/node/452, last accessed 22 November 2018.

2 International Union for Conservation of Nature and Natural Resources, 'World Conservation Strategy: Living Resource Conservation for Sustainable Development' (1980), para 1.2.
} 
advantages and disadvantages of alternative actions'. ${ }^{3}$ Framing sustainability in three dimensions - the economic, social and environmental - was reinforced in the most oft-cited definition of 'sustainable development' set out in the 1987 Brundtland Report. The Brundtland definition conceives of sustainable development as meeting 'the needs of the present without compromising the ability of future generations to meet their needs'. ${ }^{4}$ What may be even more helpful to reflect on is what the Report goes on to say about these 'needs', namely that these should be understood as 'the essential needs of the world's poor, to which overriding priority should be given'. Human concerns, such as poverty alleviation, are seen as being pressing alongside ecological concerns. Moreover, the Report in the next sub-clause acknowledges the 'idea of limitations imposed by the state of technology and social organization on the environment's ability to meet present and future needs'. So while the early more often-cited passage might seem to suggest easy reconciliation of inter-generational justice, the rest of the Report recognizes that this is far from straightforward and that intra-generational justice is also at issue.

Early accounts of economic sustainability can be traced back to the writings of John Stuart Mill and Thomas Robert Malthus. ${ }^{5}$ They tended to equate sustainability with maximizing aggregate utility. From this vantage point, the Brundtland definition of 'sustainable development' can be explained in terms of the 'savings-investment' Hartwick rule. ${ }^{6}$ This rule or principle is concerned with assessing the amount of investment needed to maintain the standard of living for future generations as exhaustible resources diminish. In other words, it recognizes that the exploitation of natural resources will result in economic growth and that this is important to the sustainability of humanity. However, those resources are not finite and, therefore, sustainable economic development requires an evaluation of the investments needed to offset the loss caused by environmental exploitation. Sustainable economic growth has the tacit goal of reducing inequalities and narrowing the gap between the rich and the poor. Environmental sustainability, on the other hand, has placed greater emphasis on the interconnection between environmental life-support systems, economic

\section{Ibid, para 1.3.}

Report of the World Commission on Environment and Development: Our Common Future (1987) available at www.un-documents.net/wced-ocf.htm, last accessed 22 November 2018, ch 2, para 1.

5 Robert Goodland, 'The Concept of Environmental Sustainability' (1995) 26 Annual Review of Ecological Systems 1.

6 See: Robert M Solow, 'Intergenerational Equity and Exhaustible Resources' (1974) Review of Economic Studies Symposium and JM Hartwick, 'Substitution Among Exhaustible Resources and Intergenerational Equity' (1978) 45(2) Review of Economic Studies 347. 
production and humanity. This school of thought frames sustainability as a natural science concept concerned with the 'maintenance of natural capital'? The strength of these earlier accounts lies in the different metrics proposed for measuring and analysing sustainability. However, if the focus were only on maintaining the stock of capital for future generations without enhancing the wellbeing of present generations, our understanding of sustainability would have a 'terribly hollow ring'. ${ }^{8}$ Such theoretical approaches are not attentive to the values that are constitutive of development.

While the concept of sustainable development emerged in the environmental context, the international institutions have tended to approach sustainability from a values-based and 'human-centred' perspective. In 1992 in Rio de Janeiro, the non-legally binding UN Resolution known as 'Agenda 21' was adopted by 178 countries at the Earth Summit and provided a programme for achieving global sustainable development. ${ }^{9}$ Combating poverty remains 'the long-term objective of enabling all people to achieve sustainable livelihoods [and] should provide an integrating factor that allows policies to address issues of development, sustainable resource management and poverty eradication simultaneously'. ${ }^{10}$ However, the human (or 'anthropocene') dimension ${ }^{11}$ enters as not only a substantive aim, but also a procedural objective. Article 10 , in particular, stresses the importance of participatory engagement in decision-making. Agenda 21 was designed to reflect a 'global consensus and political commitment at the highest level on development and environmental cooperation'. ${ }^{12}$ It recognized the significance of an open and non-discriminatory multilateral trading system for the realization of sustainable growth and sustainable development. There was acknowledgement shortly afterwards in the preamble of the 1994 Agreement establishing the WTO of the significance of 'sustainable development' as a trade objective: 'allowing for the optimal use of the world's resources in accordance with the objective of sustainable development...'. 13

7 Goodland (n5), 10

8 Amartya Sen, 'Human Development and Economic Sustainability' (2000) 28 World Development 2038.

9 Report of the United Nations Conference on Environment and Development, Rio de Janeiro, 3-14 June 1992 (United Nations publication, Sales No E93.I.8 and corrigenda), hereinafter 'Agenda 21'.

10 Article 3.4, Agenda 21.

11 For debate over the role of the anthropocene in environmental governance, see an excellent recent collection of essays, Louis Kotze (ed), Environmental Law and Governance for the Anthropocene (Hart 2017).

12 Article 1.3, Preamble, Agenda 21.

13 Available at www.wto.org/english/docs_e/legal_e/04-wto_e.htm, last accessed 22 November 2018. 
The Johannesburg Plan of Action (2002) ${ }^{14}$ built upon the implementation programme of Agenda 21 and sought to integrate the three 'independent and mutually reinforcing pillars' or dimensions of sustainable development, while maintaining the focus on poverty eradication as the primary objective. ${ }^{15}$ In this sense, it is not surprising that the commitment 'to eradicate extreme poverty and hunger' was identified as the very first of the Millennium Development Goals (MDGs). Ensuring 'environmental sustainability' was the seventh, curiously discrete MDG; while a more holistic 'global partnership for development' was envisaged in the eighth and final goal. On closer examination, the MDGs offered almost absurdly concrete 'indicators' for the achievement of each goal by 2015, enabling the calculation of measurable gains. However, by the same token, they were also criticized as target driven, taking insufficient account of local priorities and operating in donor-centric ways. ${ }^{16}$ In the meantime, the principle of sustainability (even if not regarded as binding under international law) was recognized as influential by the International Court of Justice in terms of a need to balance economic and environmental objectives. ${ }^{17}$ On the expiry of the MDG 15-year agenda, an even more integrated approach to sustainability was continued in the SDGs, which form part of the broader 2030 Agenda.

\section{THE SUSTAINABLE DEVELOPMENT GOALS 2015 AND THEIR SIGNIFICANCE}

The SDGs and the 2030 Agenda reinforce the 'human-centred' approach to sustainable development and recognize that 'eradicating poverty in all its forms and dimensions... is an indispensable requirement for sustainable development'. ${ }^{18}$ The 2030 Agenda is a 'plan of action for people, planet, and prosperity', seeking to achieve global sustainability through seventeen SDGs

14 Available at www.un-documents.net/jburgdec.htm, last accessed 22 November 2018 .

15 Article 1.2 Johannesburg Plan of Action 2002.

16 For review of this critical commentary, see Tonia Novitz, 'Core Labour Conditionalities: A Means by which to Achieve Sustainable Development' in Julio Faundez and Celine Tan (eds), International Economic Law, Economic Globalization and Developing Countries (Edward Elgar 2010).

17 Case Concerning Pulp Mills on the River Uruguay, ICJ Judgment (20 April 2010), www.icj-cij.org/docket/files/135/15877.pdf, last accessed 22 November 2018. See Virginie Barral, 'Sustainable Development in International Law: Nature and Operation of an Evolutive Legal Norm’ (2012) 23(2) European Journal of International Law 377.

18 UN Resolution 70/1, 'Transforming our World: the 2030 Agenda for Sustainable Development' A/RES/70/1 adopted by the General Assembly on 25 September 2015. 
and 169 associated targets. These span economic, environmental and social objectives, with even culture receiving careful mention. ${ }^{19}$

Many of these are concrete objectives associated with such crucial issues as poverty (SDG 1), hunger (SDG 2) and health (SDG 3). We find certain entitlements that have gained status as human rights embedded in the SDGs, such as protection from gender discrimination (SDG 5) and protection from forced and child labour (SDG 8). Not all of these values are necessarily successfully transposed in a different frame, so that freedom of association - which is fundamental to the International Labour Organization (ILO) constitution and recognized as one of its most core values in the 1998 ILO Declaration on Fundamental Principles and Rights at Work - qualified only as an 'indicator' rather than a 'target' in SDG 8.8.2. Arguably, this raises some interesting questions regarding the role of human rights within the SDGs, which are now being considered by scholars. ${ }^{20}$ It is therefore not surprising that many of the authors in our collection prefer to refer to key international instruments which are indicative of sustainability principles, rather than the abstracted entitlements under the SDGs which may not wholly map onto the content of more established instruments.

The SDGs do, however, stress the 'interdependence' of the economic, social, environmental and cultural objectives they represent. In this sense, we might link their formulation to the 'planetary boundaries' model of sustainability. Originating in the discipline of natural sciences, this model seeks to identify the 'safe operating space for humanity' through the measurement of nine environmental factors. It offers an account of the 'circular economy' which promotes the sustainable integration of economic activity and social and environmental wellbeing. The origin of the term 'circular economy' is disputed, ${ }^{21}$ but it has come to the fore in the context of Kate Raworth's treatment of 'Doughnut Economics'. She posits that our social, environmental and cultural objectives will have to be constrained by the need to live within the planetary boundaries of the globe (an 'environmental ceiling'), while respecting each person's entitlement to the resources needed for a 'social foundation' of rights

19 Sport and culture receive distinctive recognition in the 2030 Agenda document at paras 36 and 37, and are thereby arguably embedded in the various SDGs. An example is SDG 4.7 relating to education, which states that there is to be 'appreciation of cultural diversity and of culture's contribution to sustainable development'.

20 Gillian MacNaughton and Diane Frey, 'Decent Work, Human Rights and the Sustainable Development Goals' (2016) 47 Georgetown Journal of International Law 607; and Duncan French and Louis J Kotzé, Sustainable Development Goals: Law, Theory and Implementation (Edward Elgar 2018).

${ }^{21}$ For a rich overview of the various claims to its origins, see Alan Murray et al, 'The Circular Economy: An Interdisciplinary Exploration of the Concept and Application in a Global Context' (2017) 140 Journal of Business Ethics 369. 
to be respected. ${ }^{22}$ In other words, there are legitimate social, economic and cultural objectives which represent intra-generational justice, namely a better life, but which we cannot achieve without the conditions for life. So while it is entirely legitimate under SDG 16.2 to 'end abuse, exploitation, trafficking and all forms of violence against and torture of children' (which has nothing to do with environmental concerns), the methods used must apply within planetary boundaries, as we understand the logic of the SDGs.

Other SDGs are less concrete in their content, but do have overarching significance. Notable amongst these is SDG 16, which aspires to 'Promote peaceful and inclusive societies for sustainable development, provide access to justice for all and build effective, accountable and inclusive institutions at all levels'. This is no small task and what is interesting is the attempt of the drafters to dissect what such inclusion might entail in concrete terms. Under SDG 16.3, there is an undertaking to 'Promote the rule of law at the national and international levels and ensure equal access to justice for all'. This seems to cover the notion of both formal equality under the law and substantive equality, which are not easy to reconcile; but that both are present is of interest. Further, there is recognition that without transparency and accountability, it is not possible to achieve justice through institutions (under SDG 16.6). SDG 16.7 goes even further to make the case for 'responsive, inclusive, participatory and representative decision-making at all levels'.

The need for a 'global partnership' is carried forward in SDG 17, which seeks to ensure 'Policy Coherence for Development'. In this context, SDG 17.13 seeks to 'enhance global macroeconomic stability, including through policy coordination and policy coherence'. As we have observed elsewhere, there are notable connections between the SDGs and international trade, investment and finance. ${ }^{23}$ For example, SDG 2.B places the onus on the WTO to 'correct and prevent trade restrictions and distortions in world agricultural markets'; under SDG 3.B, the WTO is likewise tasked with promoting 'research and development of vaccines and medicines ... that primarily affect developing countries'. SDG 10.8 acknowledges that implementation of special and differential treatment in the WTO could have significant economic benefits, but also enable greater social and political inclusion in the global economy. Echoing the sentiments of Agenda 21, the 2030 Agenda promotes a 'universal, rules-based, open, non-discriminatory and equitable' multilateral

22 Kate Raworth, Doughnut Economics: Seven Ways to Think Like a $21^{\text {st }}$ Century Economist (Cornerstone Books 2017).

23 Clair Gammage and Tonia Novitz, 'Trade, Investment and Corporate Sustainability' in Beate Sjåfjell and Christopher Bruner (eds), Cambridge Handbook on Corporate Sustainability (Cambridge University Press 2019). 
trading system as an important part of realizing sustainable development in SDG 17.10.

Moreover, it is not just trade, but also financial aid which is identified as important. SDG 8.A includes a reminder to 'Increase Aid for Trade support for developing countries, and particularly least developed countries...', including through technical assistance; while the significance of 'financial flows' is highlighted in SDG 10.9. These targets can be read together with SDG 17.5, which urges 'investment promotion regimes for least developed countries'. For these reasons, we considered it timely in the context of the SMART project to consider whether these economic norms for sustainability, which are intended to drive trade, investment and finance, are indeed operationalized in the institutional and legal frameworks operating globally. Arguably, what we see is a shortfall, but a greater normative acknowledgement of important constraints on viewing development, or indeed sustainability, only in terms of the accumulation of economic wealth. ${ }^{24}$ What the SDGs have tried to do is enable other environmental, social and cultural values to suffuse prescriptions for economic activity, while also suggesting inclusive, participatory, transparent and accountable institutions for doing so.

\section{POLICY COHERENCE AND THE EUROPEAN UNION}

The overarching aim of SDG 17 is to 'Strengthen the means of implementation and revitalize the global partnership for sustainable development'. As participants in a European-funded project, this necessarily raised for us the issue of the EU's role as a global partner (and a significant partner in trade and development aid and finance) within this matrix. The contributors to this book come from a wide variety of backgrounds connected to countries as diverse as Australia, China, New Zealand, Malaysia, Mexico and Sri Lanka; while others hail from a range of European states, but have worked extensively on initiatives in other countries of the Global South. In this sense, we do not see our observations in this book as simply geographically constrained to a European viewpoint. Rather, at various points authors have sought to explore the economic (and arguably normative) ${ }^{25}$ strength of the EU as an actor and to consider whether in a variety of legal spheres the EU is acting responsibly with regard to sustainability and its promotion also by corporate actors.

${ }^{24}$ A process which arguably commenced with the work of Amartya Sen; see, for example, Development as Freedom (OUP 1999).

${ }_{25}$ See, for example, Jan Orbie (ed), Europe's Global Role: External Policies of the European Union (Ashgate 2008); Jan Orbie and Lisa Tortell (eds), The European Union and the Social Dimension of Globalization (Routledge 2009). 
We might expect this to be the case given that, at the EU constitutional level, the objective of 'sustainability' is codified in the Treaty on European Union (TEU). For example, Article 3(3) TEU requires the EU to 'work for the sustainable development of Europe based on balanced economic growth and price stability, a highly competitive social market economy, aiming at full employment and social progress, and a high level of protection and improvement of the quality of the environment'. It is also a principle that is intended to guide the external dimension of EU activities. Article 3(5) TEU provides that: 'In its relations with the wider world, the Union shall... contribute to peace, security, the sustainable development of the Earth, solidarity and mutual respect among peoples, free and fair trade, eradication of poverty and the protection of human rights ...' In this sense, the EU anticipated the SDGs insofar as sustainability is seen as a matter of legitimate concern for internal EU policy with respect to even highly industrialized economies; it is not only for export.

Article 21 TEU provides the legal basis for externalizing the EU's founding values in its relations with other countries and states that 'the Union's action on the international scene shall be guided by the principles which have inspired its own creation, development and enlargement'. The founding principles include 'democracy, the rule of law, the universality and indivisibility of human rights and fundamental freedoms, respect for human dignity, the principles of equality and solidarity, and respect for the principles of the United Nations Charter and international law'. Sustainability is among these principles and Article 21(2)(d) TEU states that externally the EU shall work with other countries to 'foster the sustainable economic, social and environmental development of developing countries, with the primary aim of eradicating poverty'; while Article 21(2)(f) provides that the EU shall 'help develop international measures to preserve and improve the quality of the environment and the sustainable management of global resources, in order to ensure sustainable development'. Furthermore, Article 21(3) TEU confirms that the 'external aspects of [the EU's] other policies' must be carried out in pursuit of these principles. In doing so, Article 21(2)(h) reinforces the EU's objective to 'promote an international system based on stronger multilateral cooperation and global governance'.

In the context of trade and aid, we have seen the EU take certain initiatives relating explicitly to sustainable development, such as its 'special incentive arrangement for sustainable development and good governance chapter' for the granting of tariff relief under the EU Generalized System of Preferences (GSP), which has come to be known as ' $\mathrm{GSP}+{ }^{\text {' }}{ }^{26}$ and the EU insertion of a

26 Council Regulation 732/2008 OJ L 211/1 (2008), Chapter 2, Section II. 
'sustainable development' chapter in FTAs with third countries. ${ }^{27}$ However, neither has been without criticism. For example, whereas the 2008 GSP+ Regulation was concerned with the 'effective implementation' of key international instruments, the 2012 Regulation merely applies where there is no 'serious failure' to implement the list of international instruments identified as essential to sustainable development and good governance. ${ }^{28}$ Similarly, the Comprehensive Economic Trade Agreement between the EU and Canada (CETA) is now to be scrutinized by the Court of Justice of the European Union (CJEU), following a reference brought by Belgium, ${ }^{29}$ and the content of some of its provisions (including those relating to sustainability and investment disputes) remain the subject of controversy..$^{30}$ Nevertheless, both are arguably indicative of the EU's determination to identify and to be seen as pursuing 'sustainability' objectives in external trade.

The idea of PCD at the EU level emerged in 2006 with the adoption of the first European Consensus for Development, ${ }^{31}$ and can be regarded as the EU's attempt to embrace the 'sustainability' zeitgeist of the time. In particular, the European Commission's Directorate-General responsible for development cooperation and the other directorates of the Commission took steps to measure the impacts of trade and investment on developing countries through Impact Assessment Guidelines and, more recently, through the Better Regulation

27 See, for discussion, Lore Van den Putte and Jan Orbie, 'EU Bilateral Trade Agreements and the Surprising Rise of Labour Provisions' (2015) 31(3) International Journal of Comparative Labour Law and Industrial Relations 263.

${ }_{28}$ For criticism, see Jeff Vogt, 'A Little Less Conversation: The EU and the (Non) Application of Labour Conditionality in the Generalized System of Preferences (GSP)' (2015) 31(3) International Journal of Comparative Labour Law and Industrial Relations 285.

${ }_{29}$ This has been requested following the CJEU issue of Opinion 2/15 ON 16 May 2017 (available at http://curia.europa.eu/juris/document/document.jsf?docid=190727\& mode $=1$ st\&pageIndex $=1 \&$ dir $=\& o c c=$ first $\&$ part $=1 \&$ text $=\&$ doclang $=E N \& c i d=309331$, last accessed 22 November 2018) regarding the EU-Singapore FTA and concerns Chapter 8 'Investments' and Section F 'Resolution of investment disputes...' regarding a newly devised Investment Courts System. See www.uniglobalunion.org/sites/default/ files/files/news/declaration_du_royaume_de_belgique_en_uni_global_union.pdf and https://greennews.ie/ecj-examine-legality-ceta-investment-dispute-settlement-system/, last accessed 22 November 2018.

${ }_{30}$ On the scope to build on the provisions in CETA, see, for example, http:// cjel.law.columbia.edu/preliminary-reference/2017/trade-investment-and-sustainable -development-in-ceta/, last accessed 22 November 2018.

31 See OJ C 46/1 24.2.2006, available at http://eur-lex.europa.eu/LexUriServ/ LexUriServ.do? uri=OJ\%3 AC \%3 A2006\%3 A046\%3 A0001\%3A0019\%3 AEN \%3APDF, last accessed 22 November 2018. Emphasized again in the $2011 \mathrm{EU}$ Communication on the Agenda for Change COM(2011) 637 final, Brussels, 13 October 2011. 
framework (including the Tool Kit). The collective aim of these measures is to ensure that PCD is mainstreamed across all Commission activities.

In terms of its content, EU PCD largely followed international consensus as reflected initially in the MDGs and now in the SDGs. Since 2015, for example, protection of the ILO norm of 'decent work' (as reflected in SDG 8) has re-entered the picture in the new Consensus on Development signed in June 2017.32 The 2017 Consensus notes that PCD is 'a fundamental contribution to achieving the $\mathrm{SDGs}^{\prime 33}$ and will be operationalized through a rights-based approach to development. ${ }^{34}$ It observes that universal values such as 'democracy, good governance, the rule of law, and human rights for all' are 'preconditions of sustainable development' ${ }^{35}$ and, as such, undertakes that the EU will promote universal values in its development policies. This determination to follow and accept international norms on sustainability is also arguably dictated by the EU's own constitution, since Article 208(1) TFEU provides that 'development cooperation shall have as its primary objective the reduction and, in the long term, the eradication of poverty' (connecting to MDG 1 and SDG 1). Furthermore, Article 208(2) TFEU requires that the EU and its Member States 'comply with the commitments and take account of the objectives they have approved in the context of the United Nations and other competent international organisations'.

Accordingly, this edited collection considers not only the broader dynamics of international economic law, but also how the EU acts in this sphere alongside other powerful actors, such as China and the US, given the broad consensus in MDG 8 and SDG 17 that global partnership is essential for sustainability.

\section{THE CONTENT AND COVERAGE OF THE ESSAYS IN THIS BOOK}

This book is divided into five substantive parts. The first relates to trade, the second to supply chain regulation in trade, the third to the content of investment treaties, the fourth to investment arbitration and the fifth to issues of finance (including taxation). Throughout, the authors assess the relevance and achievement of sustainability objectives in their field of study.

\footnotetext{
32 Available at https://ec.europa.eu/europeaid/sites/devco/files/european-consensus -on-development-final-20170626_en.pdf, last accessed 22 November 2018.

33 The New Consensus, above, para. 10.

34 Ibid, para. 16.

35 Ibid, para. 61.
} 


\section{$5.1 \quad$ Trade}

The essays offered in the section on trade consider, from the perspective of sustainability, the dynamics of international trade and the mechanisms and legal instruments utilized for its regulation. In so doing, the respective roles of the WTO and FTAs are considered as potential promoters of (or detractors from) sustainable development. Here we are - at least in formal theory and black-letter law - concerned solely with the actions of state parties, rather than the private actors which initiate trade relations or, indeed, investors (to which we return later in the volume).

The key WTO principle of non-discrimination is concerned with 'reciprocity' and is expressed in both the most-favoured nation (MFN) principle and the national treatment requirement. MFN requires any WTO member to receive the same privileges regarding tariffs under the General Agreement on Tariffs and Trade (GATT) or market access under the General Agreement on Trade in Services (GATS) as any other member; while the principle of national treatment requires that a WTO member not operate discriminatory measures to benefit national products or services over imported 'like' products or services. Development objectives of certain states can operate under a principle of 'special and differential treatment' (SDT) as exceptions to this principle of reciprocity (eg, see Part IV of GATT). The EU's GSP system is a case in point under the Enabling Clause. ${ }^{36}$ Environmental concerns can be raised as 'General Exceptions' under Article XX of GATT and Article XIV of GATS, which enable unilateral state action under certain limited conditions. Increasingly, normative considerations, such as those relating to social and environmental concerns, are being cited as 'legitimate objectives' for the creation of regulatory measures under the Agreement on Technical Barriers to Trade $^{37}$ and as justifications for the use of subsidies under the Subsidies and Countervailing Measures (SCM) Agreement. ${ }^{38}$

36 The Enabling Clause: 'Differential and More Favourable Treatment Reciprocity and Fuller Participation of Developing Countries' - Decision of 28 November 1979 L/4903 - appended to GATT (which continues to apply as part of GATT 1994 under the WTO), available at www.wto.org/english/docs_e/legal_e/enabling1979_e.htm, last accessed 22 November 2018. See also Omphemetse S Sibanda Sr, 'Towards a Revised GATT/WTO Special and Differential Treatment Regime for Least Developed and Developing Countries' (2015) 50 Foreign Trade Review 31.

37 See Gabrielle Marceau, 'The New TBT Jurisprudence in US - Clove Cigarettes, WTO US - Tuna II, and US - COOL' (2013) 8 Asian J WTO and Int'l Health L \& Policy 1.

${ }_{38}$ See Dirk de Bièvre, Ilaria Espa \& Arlo Poletti, 'No Iceberg in Sight: On the Absence of WTO Disputes Challenging Fossil Fuel Subsidies' (2017) 17 International Environmental Agreements 411; Steve Charnowitz and Carolyn Fischer, 'Canada - 
Daniel Szabo's analysis of sustainability-related trade barriers focuses on what are understood to be 'like products' for the purpose of their treatment under GATT. For example, is asbestos simply another building material which should be treated like any other? ${ }^{39}$ Essentially, if their process and production methods cannot be distinguished, the products should be bound by the same rules, despite their effects from a sustainability perspective. Not satisfied by this facet of WTO jurisprudence to date under the Dispute Settlement Understanding (DSU), Szabo goes on to explore the capacity of states to take unilateral action under the 'General Exceptions' provisions. Here he finds an evolving case law on the relevance of environmental protections under Article XX, culminating in litigation on the EC Seals case, where the objective of EU measures was regarded as coming within the public morals exception, but it was found that the execution was not proportionate. ${ }^{40} \mathrm{He}$ also considers the special case of renewable energy trade, in which both the WTO and its members have been active in the past decade. He considers whether the WTO's current framework is capable of handling these situations and what outcomes can be expected from such cases.

From an external perspective, we note that there remains potential for the SDGs to influence the findings of panels within the DSU, not least because sustainable development is a legitimate objective of the WTO as expressed in the Marrakesh Agreement. An interesting example is Brazil-Certain Measures Concerning Taxation and Charges (Brazil-Taxation). ${ }^{41}$ Brazil had offered information technology subsidies which were arguably in breach of the WTO Agreement on Trade-Related Investment Measures and the SCM Agreement. Nevertheless, Brazil cited the 'digital divide' as a reason for its actions, making reference to Target 8.F of the MDGs, which encouraged states to cooperate 'with the private sector' so as to 'make available the benefits of new technologies, especially information and communications'. In this respect, Brazil referred also to the MDG Report of 2015 which expressed concern that

Renewable Energy: Implications for WTO Law on Green and Not-So Green Subsidies' (2015) 14 World Trade Review 177; Luca Rubini, 'Ain't Wastin' Time No More: Subsidies for Renewable Energy, the SCM Agreement, Policy, Space and Law Reform' (2012) 15 Journal of International Economic Law 525.

39 WTO, European Communities: Measures Affecting Asbestos and Asbestos-Containing Products - Report of the Appellate Body (12 March 2001) WT/ DS135/AB/R, paras 98-99.

40 See Appellate Body Reports, European Communities - Measures Prohibiting the Importation and Marketing of Seal Products, 2014, 174.

41 Brazil-Certain Measures Concerning Taxation and Charges, DS472: Panel Report circulated" 30 August 2017, available at www.wto.org/english/tratop_e/dispu e/472 497r e.pdf, last accessed 22 November 2018. We are grateful to Dr Caroline $\bar{F}$ oster at the University of Auckland Law School for bringing this case to our attention. 
'ICT access and use are unequally distributed within and between countries', and that 'it will be essential to address the widening digital divide. Only then will the transformative power of ICTs and the data revolution be harnessed to deliver sustainable development for all' ${ }^{42}$ This raises the potential to cite the SDGs in future cases and even findings of the associated High Level Political Forum. ${ }^{43}$ The other point to note is the future of the DSU given the disarray in which the Appellate Body currently finds itself, such that the appeal from the Brazil case or cases similar to EC Seals may not be determined in the authoritative ways we have now come to expect. ${ }^{44}$

Szabo offers an example of EU conduct in trade in the form of the $E C$ Seals case, whereas Clair Gammage conducts a more detailed investigation of EU attempts to promote sustainable development in the context of FTAs. Increasingly, the EU has sought to embed social values as part of progressive trade agreements with countries across the globe. This chapter focuses on the 'spectrum' of rights and norms contained in EU FTAs and explores the scope of their enforceability. Since the conclusion of the EU-Korea FTA, standalone 'sustainable development' chapters have become commonplace in EU trade agreements. A critical interrogation of these chapters reveals weaknesses in the institutional compliance mechanisms, but Gammage proposes that it may be possible to strengthen the EU's enforcement approach beyond its current 'soft' confines. In this respect, there is scope for more effective impact assessment and, in accordance with the inclusive approach promoted by SDG 16, more meaningful engagement with civil society actors. Gammage argues that FTAs are being used as 'levers' to promote social norms across transnational spaces and concludes that, notwithstanding the limitations of sustainable development chapters, the EU is emerging as a sustainable development actor in the context of free trade negotiations.

Franz Ebert's analysis of the genesis of the Comprehensive and Progressive Agreement for Trans-Pacific Partnership (CPTPP) takes us beyond the role of the EU as an external economic actor, enabling examination of the preferences of other states in the international community. This is a species of FTA which has come to be known as a 'mega-regional' agreement, given the breadth of its coverage. Ebert observes the relevance of SDG 8 (to the extent that this raises issues of ILO 'decent work'), but also SDGs 16 and 17, arguing that

\footnotetext{
42 Ibid, at para. 7.563 .

43 See https://sustainabledevelopment.un.org/hlpf, last accessed 22 November 2018.

44 See, for the resistance of the US Trade Representative to appoint WTO Appellate Body Members, Bradly J Condon, 'Captain America and the Tarnishing of the Crown: The Feud Between the WTO Appellate Body and the USA' (2018) 52(4) Journal of World Trade 535.
} 
if their effect is not merely to be rhetorical, they require 'the integration of employment and workers' rights concerns into the general global governance framework, and its economic governance limb in particular'. Initially, the US was the key driver for enlargement of what was then just the Trans-Pacific Partnership (TPP), but as is common in the drafting of US trade agreements, did not seek to protect 'sustainable development' per se - instead, the TPP contains a specific Chapter 19 dedicated to 'Labour Standards'. Ebert is critical of the limited content of the chapter in terms of its partial transposition of ILO standards and (like Gammage) is sceptical of the force of the enforcement provisions. However, he points to the pre-ratification stage as crucial and notes that the significant work done by the US Trade Representative in pursuing bilateral 'labour action plans' (2015) - which were expressly linked to the TPP Labour Chapter for Vietnam, Malaysia and Brunei, and which had capacity-building effects - may actually assist in ensuring the efficacy of their undertakings. Today, the US Trump Administration has withdrawn from ratification of the now re-named CРТPP and seems more likely to seek to challenge its operation. In this context, Ebert considers whether the chapter could survive a challenge under Article XX of GATT, the 'General Exceptions' provision examined by Szabo. The theoretical residual force of WTO rules, along with their limitations in promotion of sustainability, is laid bare.

This part of the book highlights various barriers to the 'policy coherence' and global partnership for sustainable development that SDG 17 seeks to promote. First, the rules under which the WTO operates do not readily facilitate sustainability objectives; instead, they feature as 'General' or indeed other 'Exceptions'. There is an open question as to whether the WTO as currently constructed can facilitate the policy coherence needed. Also, while the WTO provides an overarching framework which governs their legitimacy, FTAs are more likely now to regulate the terms of trade between states. Here the EU has the power to introduce 'sustainable development chapters' and the US to prompt pre-ratification plans for labour standards (and thereby some sustainability) compliance. However, where such powerful global actors (eg, the US) change their political tune, the issues regarding diverse forms of governance (and their implications for enforcement) are highlighted. Concerns arise regarding access to justice - certainly for developing countries in the Global South, but also regarding representation of those affected by FTAs under individually designed dispute mechanisms for the purpose of a given agreement. This, in turn, arguably affects accountability on the global stage.

\subsection{Supply Chains}

Contemporary modes of manufacture and service provision, combined with forms of technological change, have led to significant transnational 
cross-border sites of production and delivery. Multinational corporate enterprises (MNEs) subcontract across national boundaries and, in this way, utilize different legal regimes and lower costs in specific countries. In so doing, there is scope to distance the commercial enterprise which ultimately profits from the labour on which it draws and the actions of its subcontractors insofar as they affect the environment or other pillars of sustainability. This second part of the book examines how supply chains operate and assesses options for their regulation.

Supply chains may be understood as 'the cross-border organization of the activities required to produce goods or services and bring them to consumers through inputs and various phases of development, production and delivery' ${ }^{45}$ In the literature on supply chains, there is frequent reference to "commodity chains' in the sphere of political economy, namely 'networks of [labour] and production processes whose end is a finished commodity'. ${ }^{46}$ In this body of research, the consumption of particular services at various 'nodes' is given considerable attention, alongside the ways in which cheap labour can be drafted to make the production of goods profitable and skilled labour imported to satisfy supply side problems. ${ }^{47}$ In a more positive fashion, supply chains (operating through the cross-border production of commodities) can be understood as 'global value chains', to the extent that value is added at each stage (and in each country) of the process. Policy makers in the World Bank have proposed that value not only should be created in the Global North, where the product is designed, but also should extend to (even multiple) countries in the Global South so as to fuel development. ${ }^{48}$ The ILO also sees the benefits for workers in developing and emerging countries in the Global South of global 'value' chains that provide 'new opportunities for employment..., including

45 ILO, Report IV: Decent Work in Global Supply Chains, ILC, $105^{\text {th }}$ Session (Geneva: ILO, 2016), at 2. Much of the analysis below is further taken from Tonia Novitz, 'Supply Chains and Temporary Migrant Labour: The Relevance of Trade and Sustainability Frameworks?' in Diamond Ashiagbor (ed), Re-Imagining Labour Law for Development: Informal Work in the Global North and South (Hart/Bloomsbury 2019, forthcoming).

46 Terence K Hopkins and Immanuel Wallerstein, 'Commodity Chains in the World Economy prior to 1800' (1986) 10(1) Review 157 at 159 cited in Gary Gereffi and Miguel Korzeniewicz (eds), Commodity Chains and Global Capitalism (Westport 1994) at 2.

47 Stephanie Ware Barrientos, "Labour Chains": Analysing the Role of Labour Contractors in Global Production Networks' (2013) 49(8) The Journal of Development Studies 1058.

48 For a very positive view of their operation and its development potential, see Daria Taglioni and Deborah Winkler, 'Making Global Value Chains Work for Development' (2014) The World Bank-Economic Premise, Number 143, especially at $1-2$ and 8 . 
for workers who had difficulty accessing wage employment or formal jobs, such as women, young people and migrant workers' ${ }^{49}$ However, there are dangers for migrant workers in supply chains by virtue of the ways in which they enter another country for work. It has been acknowledged that 'the cross-border flows of workers have also resulted in a greater risk of forced labour and trafficking in persons', and that while MNEs may take action to prevent such practices, 'there is a risk they may become associated with forced labour through business links to contractors and suppliers who may conceal unlawful practices' ${ }^{50}$ In this respect, a report of the ILO on supply chains in 2016 mentioned 'enforcement gaps' and 'fragmentation of norms', alongside particular difficulties for those 'in an irregular situation and in the informal economy'. ${ }^{51}$ In the sphere of supply chains, then, we once again see problems arising from diverse and fragmented global governance regarding sustainability and issues regarding access to justice. New regulatory initiatives are emerging, but are identified as imperfect by our contributors. Cautionary tales are told in both contributions to this section of our book.

In their chapter, Kasey McCall-Smith and Andreas Rühmkorf observe that global supply chains have repeatedly been in the spotlight for gross violations of human rights. They see this as a breach of corporate social responsibility (CSR), which is synonymous (in their field of inquiry) with sustainability. Human rights breaches and violations of environmental and labour standards occur in factories that are often located in so-called 'developing countries' of the Global South with weak laws and/or legal enforcement mechanisms. Due to public pressure and on reputational grounds, transnational corporations have, for some decades now, addressed those issues through voluntarily adopted private governance CSR initiatives. They consider the evolution of supply chain due diligence measures with an eye to correction of past trends. In so doing, they recognize the role that public international, regional and domestic law can play in promoting due diligence.

Starting with the UN Global Compact, they consider the normative influence of such measures. Their focus is on the UN Guiding Principles on Businesses and Human Rights (UNGPs), ${ }^{52}$ the Organisation for Economic Co-operation and Development (OECD) Guidelines for Multinational Enterprises ${ }^{53}$ and the

\footnotetext{
ILO (n46), 17.

Ibid, at 26.

Ibid, at 25 and 32 .

2 UN Guiding Principles on Business and Human Rights, UN Doc A/HRC/17/31 (21 March 2011) annex (UNGPs).

53 OECD, Guidelines for Multinational Enterprises (OECD Publishing 2011), www .oecd.org/daf/inv/mne/48004323.pdf, last accessed 22 November 2018. The UNGPs were incorporated explicitly into the Guidelines for MNEs.
} 
OECD Due Diligence Guidance for Responsible Supply Chains of Minerals from Conflict-Affected and High-Risk Areas. ${ }^{54}$ Drawing on these sources, they find a common pattern for effective implementation of the due diligence duty. While the due diligence frameworks vary slightly, they operate in mutually supportive ways, also informing national legislation and practice. In this respect, they examine two examples: the UK Modern Slavery Act and the US Dodd-Frank Act. Both are 'light touch' and encourage transparency as a route to due diligence scrutiny, while not being positioned in ways that enable more stringent enforcement. Their concern focuses on the failure to access remedies for those persons actually affected by MNE conduct in the context of supply chains. They see this as an obstruction to the realization of several SDG targets, including SDG 16 which promotes 'the rule of law at the national and international levels' and aims to 'ensure public access to information and protect fundamental freedoms'.

What is exciting about the EU Forest Law Enforcement, Governance and Trade (FLEGT) initiative, outlined by Karin Buhmann and Iben Nathan in their chapter, is that it blends hard and soft law to achieve globally recognized environmental sustainability objectives. There is a hard law basis to FLEGT, to be found in two EU Regulations. ${ }^{55}$ The 2005 Regulation awarded privileged access to the EU market for states that entered into a specific Voluntary Partnership Agreement (VPA), entailing the creation of an assurance system that the timber had been felled lawfully. The subsequent 2010 Regulation addressed the limited number of VPAs which required market actors placing timber on the EU market to undertake due diligence to ascertain the legality of the timber. ${ }^{56}$ As Buhmann and Nathan report, the 'smart mix' regulation approach which is reflected in FLEGT was recommended by the UNGPs as a regulatory approach by states to promote business respect for human rights, ${ }^{57}$ and (as identified by McCall Smith and Rühmkorf) is indicative of the reach and influence of that instrument and has been embraced explicitly by the European Commission. ${ }^{58}$

54 OECD, Recommendation of the Council on Due Diligence Guidance for Responsible Supply Chains of Minerals from Conflict-Affected and High-Risk Areas, C/MIN(2011)12/FINAL (25 May 2011).

55 Council Regulation 2173/2005 of 20 December 2005 on the establishment of a FLEGT licensing scheme for imports of timber into the European Community OJ 2005 L 347/1.

${ }_{56}$ Regulation (EU) 995/2010 of the European Parliament and of the Council of 20 October 2010 laying down the obligations of operators who place timber and timber products on the market OJ $2010 \mathrm{~L} 295 / 23$.

$57 \quad$ See n52.

58 Commission Communication of 25 October 2011, 'A Renewed EU Strategy 2011-2014 for Corporate Social Responsibility’ COM(2011)681. 
However, Buhmann and Nathan also observe a tension between the EU's de facto imposition extraterritorially of sustainability environmental standards (being the ethical actor that it tries to be under policy coherence) and the rule of law and democracy in VPA partner states. This follows from the extreme imbalance in power between the EU and those recipients of supply chain trade access under FLEGT, such as Indonesia. The authors argue that this may have unintended consequences in terms of potentially diminishing applicable environmental standards which are recognized by the local community as vital to sustainability. They observe that 'the capacity of a law-maker (the EU) that is accountable only to its own legal constituency (EU Member States and their citizens) to generate extraterritorial changes through the trade-based power of the market highlights potential legitimacy and accountability deficiencies'. We suggest that there is a further argument to be made here: democratic participatory processes should not be thought of as lying outside 'sustainability', but are a crucial aspect of its realization. While SDG 16.B sets out the need to promote and enforce 'policies for sustainable development', this is prefaced by SDG 16.17, which sets out the target to 'ensure responsive, inclusive, participatory and representative decision-making at all levels'. These legitimacy and accountability deficiencies therefore are deeply connected to sustainability objectives.

\subsection{The Content of Investment Treaties}

There were over 3300 investment treaties in operation by 2015, with an ever-greater number incorporating human rights provisions (including core ILO labour standards) and clauses directed towards the environmental dimensions of sustainability. However, at the same time, we have recently witnessed growing disillusionment with the constraints that bilateral investment treaties (BITs) and other treaties can place on state policy relating to sustainability objectives, leading some states (notably BRICS countries such as India and South Africa) to withdraw from BITs or refuse to participate in negotiations for their future conclusion..$^{59}$

Amy Man, in her chapter entitled 'Old Players, New Rules: A Critique of the China-Ethiopia and China-Tanzania Bilateral Investment Treaties', sees an opportunity in the drafting of investment treaties for the achievement of sustainable development objectives. She considers how the concept could be

59 See Jane Kelsey, 'The Crisis of Legitimacy in International Investment Agreements and Investor-State Dispute Settlement' (2018), available at https://judicialpowerproject .org.uk/jane-kelsey-the-crisis-of-legitimacy-in-international-investment-agreements -and-investor-state-dispute-settlement/, last accessed 22 November 2018. 
embedded in the text of BITs 'as an explicit reminder to contracting parties that measures must be adopted in a sustainable and equitable manner'. Here she considers the ways in which China has deviated from standard norms in its investment treaties with Ethiopia and Tanzania, offering new models for such instruments.

The investment agreement with Ethiopia in 1998 was concluded in the second stage of China's international trade ambitions, when there was growing integration into the global economy, but China was predominantly a capital importing state. As one would expect, the terms of the agreement with Ethiopia, despite the poverty of the latter, expressed a parity of treatment which reflected China's sense of its own vulnerability. The standard provisions regarding fair and equitable treatment of investors were present, as was the MFN principle, but notably the requirement for national treatment was absent. It may also be noteworthy that while the agreement referred restrictively to expropriation, nationalization or similar measures, it did not prohibit explicitly 'indirect expropriation' which has been used to challenge environmental and social policy regulations introduced by states which create indirect costs for investors. What was arguably distinctive about China's conduct in its negotiations with Ethiopia at this stage was that the representatives of the state did not necessarily see themselves as inevitably the investor as compared to the target of investment. It is interesting that in a later Germany-China BIT (2003), there was only a one-sided national treatment clause to be observed by Germany rather than China, and that the investment agreement between China and the Association of Southeast Asian Nations contains no indirect expropriation clause. ${ }^{60}$

The investment agreement concluded by China with Tanzania in 2014 is more elaborate, but not necessarily any less favourable towards Tanzania as the more likely recipient state. An example is Article 10, which specifically recognizes that abiding by investment obligations should not come at the expense of other societal obligations. Another example is the inclusion of a provision on national treatment, which provides scope for considerable exceptions in the context of development - namely that under Article 3.2, the parties are permitted to 'grant incentives or preferences to its nationals' on the basis of promoting local entrepreneurship. Both are interesting normative developments and precedents for sustainability.

60 See Wei Shen, 'Leaning Towards a More Liberal Stance? - An Evaluation of Substantive Protection Provisions under the New ASEAN-China Investment Agreement in Light of Chinese BIT Jurisprudence' (2010) 26(4) Arbitration International 549 at 557 and 576. 
Another potential opportunity for shaping the content of investment treaties is offered by Shamila Dawood in her chapter written from a developing country perspective. She argues for a principle of 'common but differentiated responsibilities' (CBDR), ${ }^{61}$ akin to that of SDT operating in the WTO, which would apply to environmental and other social commitments undertaken by developing countries in the context of investment treaties. Ideally, that principle would allow scope for democratic debate internal to a contracting state on relative priorities for measures to be taken, which we have seen constrained by the EU FLEGT scheme, as discussed above. The national determination of priorities would not then be hindered by an investor relying on indirect expropriation and fair and equitable treatment clauses, or even sustainability provisions.

A powerful aspect of Dawood's analysis is her understanding of CBDR as linked to the idea of equity (inter- and intra-generational justice), which is a crucial feature of sustainable development. This would embrace 'equality, equity and participation', which as we have seen are all features of the SDGs. Further, she refers to the importance of developing countries' involvement in drafting international treaties and setting international norms, including the determination of domestic implementation. In this respect, her analysis echoes the issues raised in SDG 10.6, which seeks to 'ensure enhanced representation and voice for developing countries in decision-making in global international economic and financial institutions in order to deliver more effective, credible, accountable and legitimate institutions'; and SDG 16.8, which aims to 'broaden and strengthen the participation of developing countries in the institutions of global governance'. For this reason, she advocates full disclosure of environmental-related issues at the negotiation stage, to be addressed in a balanced manner sensitive to the capacities and needs of the investor and state parties. In this sense transparency can also help to ameliorate the disparities in bargaining power between parties.

The CPTPP and CETA, as noted in section 5.1, both set out a distinctive chapter regarding investment flows between the parties. Arguably, both break new ground insofar as they contemplate greater scope for a right to regulate and implicitly place restrictions on investor compensation when environ-

61 Duncan French, 'Developing States and International Environmental Law: The Importance of Differentiated Responsibilities' (2000) 49 International Law and Comp. Law Quarterly 35; and Christopher D Stone, 'Common But Differentiated Responsibilities in International Law' (2004) 98(2) American Journal of International Law 276. See also for contemporary perspectives, Freya Baetens (ed), Investment Law within International Law: Integrationist Perspective (Cambridge University Press 2013). 
mental and other sustainability policies are pursued. ${ }^{62}$ Nevertheless, it seems that each set of provisions (when in force) will require individual case-based examination and determinations in case of a dispute. What is arguably more distinctive regarding CETA is the provision which contemplates establishment of an International Investment Court. This would overcome a variety of practical obstacles for current litigant investors and respondent states, whereby there can be in dispute over the appropriate venue for arbitration, the appointment of appropriate arbitrators and the norms that will determine the outcome of any dispute. ${ }^{63}$ However, there seems likely to be hostility from the CJEU to such an initiative, which detracts from the powers of the former. The matter is currently the subject of a reference by Belgium. ${ }^{64}$

\subsection{Investment Arbitration}

Enrique Boone Barrera has identified the Bilcon case as emblematic of the ways in which environmental sustainability protections can be challenged under investment treaties. ${ }^{65}$ In that situation, the arbitral panel observed that the state was entitled to take steps to protect the environment, but in so doing had to respect the 'legitimate expectations' of the investor or compensate accordingly. ${ }^{66}$ There is therefore a tension between the right to regulate and the need to prevent expropriation, whether direct or indirect. Further, in the sphere of development objectives, there can be a tension between the promotion of infant industries at the national level for purposes of economic and social sustainability and formal legal obligations towards an investor regarding 'fair and equitable treatment' or even 'national treatment'. Much depends, as noted above, on how the investment instrument in question is drafted. So the different wording of BITs that China has concluded with Germany versus

62 Caroline Henckels, 'Protecting Regulatory Autonomy through Greater Precision in Investment Treaties: The TPP, CETA, and TTIP' (2016) 19(1) Journal of International Economic Law 27.

${ }^{63}$ August Reinisch, 'Will the EU's Proposal Concerning an Investment Court System for CETA and TTIP Lead to Enforceable Awards? The Limits of Modifying the ICSID Convention and the Nature of Investment Arbitration' (2016) 19(4) Journal of International Economic Law 761.

64 Requested 6 September 2017 - see http://hsfnotes.com/arbitration/2017/09/ 12/belgium-asks-for-the-cjeus-opinion-on-the-compatibility-of-the-investment-court -system-with-european-law/, last accessed 22 November 2018.

65 Clayton/Bilcon v Government of Canada Case No 2009-04 (17 March 2015) Award on Jurisdiction and Liability at paras 595-598, 602, 734-738, available at www.italaw.com/sites/default/files/case-documents/italaw4212.pdf, last accessed 22 November 2018.

66 Ibid, paras 531-3. 
Tanzania will be determinative. However, a more fundamental issue is how more standard economic entitlements of an investor are to be balanced against the concerns of the local population on environmental and social issues.

The standard approach is one in which the investor's economic interests, as in Bilcon, have prevailed. ${ }^{67}$ However, there are indications in the jurisprudence emerging in arbitral awards determined under the ICSID Convention that alternatives are possible. Building upon John Ruggie's recommendations on the drafting of investor-state contracts, Boone Barrera's chapter offers an approach to the incorporation of human rights in investor-state arbitration, taking into consideration the powers and limitations of arbitral tribunals.

Ahmad Ghouri's chapter suggests that it may be possible to utilize other international instruments (which seek to promote sustainability and human rights) as bases for interpretation under Articles 31 and 32 of the Vienna Convention on the Law of Treaties. He cites the established principles in the Tecmed case ${ }^{68}$ which enable recourse to human rights jurisprudence of the European Court of Human Rights and the Inter-American Court of Human Rights to determine whether there has been expropriation in the sense of disproportionate interference with property rights. This could be extended to reference to the object and purposes of the ICSID Convention concerning 'development' objectives in the identification of what 'investment' is covered by a BIT and ICSID arbitration. ${ }^{69} \mathrm{He}$ observes that the task is more straightforward where the investment treaty in question incorporates sustainability objectives.

It is also possible to take a more imaginative approach, utilizing the idea of 'sustainability' as a principle entailing a balancing exercise with reference to the idea of the 'reasonable person'. This is the suggestion of Ying-Jun Lin in her chapter. For instance, in the El Paso case, the tribunal stated that 'if the circumstances change completely, any reasonable investor should expect that the law also would drastically change'. ${ }^{70}$ It indicated that there will be a residual right to regulate, because this is indeed reasonable: 'no reasonable investor can have such an expectation [of a freeze of the legal system] unless very specific commitments have been made towards it or unless the alteration of the legal

${ }^{67}$ Compania del Desarrollode Santa Elena, SA v Republic of Costa Rica, ICSID Case No ARB/96/1, Final Award, paras 71-72 (17 Feb 2000), 15 ICSID Rev 167 (2000).

${ }_{68}$ Técnicas Medioambientales Tecmed, SA v United Mexican States, ICSID Case No ARB (AF)/00/2, Award of 29 May 2003, at 20, para 63.

${ }_{69}$ See Tokios Tokelés $v$ Ukraine, ICSID Case No ARB/02/18, Dissenting Opinion of the President of the Tribunal, Prosper Weil of 29 April 2004, paras 2-4.

70 El Paso Energy Co v Argentina, ICSID Case No ARB/03/15, Award, 31 October 2011, at para 363 . 
framework is total. ${ }^{71}$ Further, the reasonableness test can be taken to operate in relation to whether the state in question is acting reasonably. ${ }^{72}$ In this sense the Tecmed arbitration can be viewed as illustrative of the potential for use of a 'reasonable man' standard, referring to the extent to which a state's action would be regarded as arbitrary by a reasonable and impartial man, the question being 'what a reasonable and unbiased observer would consider fair and equitable...' ${ }^{73}$ The difficulty, however, is a failure of subsequent arbitral tribunals to provide more detailed analysis of how such an assessment can be made.

This is all the more problematic given recent research by the Oslo PluriCourts team into the outcome of investment arbitration for developing countries of the Global South, namely that foreign investors win in only 17 per cent of International Trade Administration (ITA) cases brought against high-income respondent states, but in 62 per cent of ITA cases brought against low-income respondent states. The team comments that the fact that 'foreign investors either win or settle close to 80 per cent of all ITA cases against low-income states remains striking'. They conclude by pointing to the tremendous significance of the payment of an award by a low-income country to an investor, citing the case of Ecuador where a recent payment was equivalent to the size of the country's health budget. ${ }^{74}$ We note that ICSID and UNCITRAL are seeking consistently to improve procedures and recognize the significance of the 2014 Convention on Transparency in Treaty-based Investor-State Arbitration applied in CETA.

\subsection{Finance and Tax}

It is self-evident that international financial markets have a considerable effect on the capacity of states to engage in forms of trade and private actors to engage in investment. Finance also affects the ability of states to pursue various social and economic programmes which promote sustainable development and thereby the wellbeing of citizens and the environment. The experience of sovereign debt has the capacity to reduce democratic sovereignty

\footnotetext{
$71 \quad$ Ibid, para 374.

72 Lemire v Ukraine II, ICSID Case No ARB(AF)/98/1, Decision on jurisdiction and liability, 14 January 2010.

73 Tecmed (n68), at para 166.

74 Occidental Petroleum Corporation and Occidental Exploration and Production Company $v$ Republic of Ecuador (II), ICSID Case No ARB/06/11, 5 October 2012. Discussed in Daniel Behn, Tarald Laudal Berge and Malcolm Langford, 'Poor States or Poor Governance? Explaining Outcomes in Investment Treaty Arbitration', paper delivered at Oslo SMART Conference on Trade and Investment May 2017, available on SSRN at https://papers.ssrn.com/sol3/papers.cfm?abstract_id=2978546, last accessed 22 November 2018.
} 
and independent regulatory design of a country's autonomy. ${ }^{75}$ Indeed, there is an increasing blurring of the line between investment and sovereign debt bonds and other forms of so-called indirect investment, which causes dilemmas for regulation. ${ }^{76}$ In this context, there has been considerable criticism by UN experts of the ways in which structural adjustment - particularly in its new forms of austerity entailing reduction of public spending - impacts upon development and the broader economic, social and environmental pillars of sustainability. ${ }^{77}$

In his chapter, Benjamin Richardson identifies a variety of ways in which private funding entities can act sustainably (and ethically) in their investments globally. One example offered by Richardson refers to the ways in which trust deeds are drafted or can be interpreted which may hold potential for fossil fuel divestment. There can also be incentives to avoid complicity in environmental harms by virtue of potential exposure to reputational harms. While drawing on national laws for their force, he observes that such corporate initiatives can also be reinforced through international initiatives, such as the UNGPs.

Celine Tan's chapter prompts us to pay attention to the ways in which 'blended finance' is channelled by international institutions such as the World Bank group and the EU, but progressively dominated by private financial capital. While providing a rich vein of much-needed funding to build capabilities for sustainability, difficulties arise in separating out the accountability of public and private actors, especially regarding the imposition of conditionality for lending. ${ }^{78}$ As Tan observes, the engagement of commercial financial sector actors in international development finance focuses on 'asset clauses' designed

75 Yuri Biondi, 'Sovereign Debt Restructuring, Refinancing and the Financial Market' (2016) 6(3) Account Econ Law 179, responding to the analysis of Odette Lienau, Rethinking Sovereign Debt: Politics, Reputation and Legitimacy in Modern Finance (Harvard University Press 2014).

76 See the issue of EU competence in relation to 'indirect investment' discussed in EU-Singapore Free Trade Agreement Opinion 2/15 ON 16 May 2017 (available at http://curia.europa.eu/juris/document/document.jsf?docid=190727\&mode= 1st\&pageIndex $=1 \& \operatorname{dir}=\& o c c=$ first $\&$ part $=1 \&$ text $=\&$ doclang $=E N \& c i d=309331$, last accessed 22 November 2018).

77 For concern expressed by the Independent Expert on the effects of foreign debt and other financial obligations of states, see the reports issued in 2017 available at http://ap.ohchr.org/documents/dpage_e.aspx?si=A/HRC/34/57; and on the EU those at http://ap.ohchr.org/documents/dpage_e.aspx?si=A/HRC/34/57/Add.1, both last accessed 22 November 2018.

78 Blended Finance Innovators (2016), 'Improving Impact: Increasing Blended Finance to achieve the Sustainable Development Goals', Discussion Draft, 1 October 2016, www.meda.org/investment-publications/286-improving-impact-increasing -blended-finance-to-achieve-the-sustainable-development-goals/file, last accessed 22 November 2018. 
to secure financial returns to investors while de-prioritizing non-commercial sustainability objectives. Further, the underlying policy framework of blended finance privileges private solutions over public approaches (by democratically elected governments) to a range of global and national public goods. Such practices again call into doubt the capacity for achievement of SDG 16.7 such that there is 'responsive, inclusive, participatory and representative decision-making at all levels'.

Finally, the chapter authored by Irene Lynch Fannon examines the 'Apple Tax Story', which suggests to us that, in constructing reliable sources of domestic state revenue, there may well be a case for transnational agreement. Taxation, as she notes, can be linked to the achievement of various SDGs - for example, the alleviation of poverty (SDG 2) and reducing economic inequalities (SDG 10) as well as the provision to citizens of good health and wellbeing (SDG 3) and quality education (SDG 4). We note, in this context, the significance of the European Commission finding that Ireland gave illegal tax benefits to Apple of over $€ 13$ billion, which effectively denied Irish citizens a significant income stream. ${ }^{79}$ At the time of writing, Ireland offers a low corporate tax rate (of 12.5 per cent) as part of a national strategy to attract foreign direct investment into Ireland and thereby 'create jobs'. However, the curious apportionment of Apple Inc management across Ireland, the US and other states enabled (as the Commission observed) Apple Inc 'to pay an effective corporate tax rate of 1 per cent on its European profits in 2003 down to 0.005 per cent in 2014'. This kind of situation has been addressed by international institutions such as the OECD, which has launched a Base Erosion and Profit Shifting Project (BEPS-Final Report 2015). Likewise, the EU Anti-Tax Avoidance Package (2016) was designed to address legal loopholes which are central to these activities. However, the resistance to EU regulation, which Lynch Fannon has observed, suggests that complex issues of sovereignty and economic policy remain at issue.

\section{CONCLUSION}

We have already seen how international, regional and national mechanisms now interact in complex ways involving a myriad of public, private and hybrid actors posing particular problems. And yet, we would say, while there are obvious barriers to policy coherence internationally, regionally and domestically, there is significant impetus for the time being to overcome these to

79 See the European Commission finding that Ireland gave illegal tax benefits to Apple of over Euro 13 billion: http://europa.eu/rapid/press-release_IP-16-2923_en .htm, last accessed 22 November 2018. 
achieve sustainability. There are a range of concrete measures which could be taken by the EU and other actors at all levels to realise sustainability objectives.

Regarding diverse forms of governance, we consider it important to build multilateral versus EU initiatives. While the FLEGT scheme and the proposals for a CETA international investment court system are innovative, and in many ways laudable, multilateral consensus may be preferable. The voices of democratic institutions and citizens of all countries will need to be protected through such initiatives as stakeholder forums, corporate structures and various forms of scrutiny and litigation. South-South agreements must be respected, so that conflicting obligations are not placed in EU-South FTAs or mega-regional agreements which would diminish trade flows and capacity for independent determination of trade relations between parties of equal bargaining power. ${ }^{80}$

Furthermore, and notwithstanding the significant difficulties regarding access to justice in a variety of forums for dispute resolution on the international stage, it is possible to take measures to secure the access of developing (low-income) states to adequate legal advice and representation in WTO dispute settlement. Improving access for interested stakeholders, such as environmental groups, and also employer and worker representatives to bring complaints under FTAs is another way in which non-state participation and voice can be strengthened. In the context of supply chains, consumers and workers (as well as national governments) should be given greater voice in due diligence procedures and complaints regarding funding conditionality.

Accordingly, we see scope for the EU to reconsider its own rules regarding standing at the CJEU for third-country states, non-governmental organizations and nationals affected by EU trade, investment and finance activities. Furthermore, and as an emergent sustainable development actor, we see an important role for the EU and its institutions in campaigning internationally for greater technical support and financial assistance to developing low-income states currently disadvantaged within WTO, ICSID and other structures. The UNCITRAL 2014 Convention on Transparency in Treaty-based Investor-State Arbitration, applied in CETA, marked a significant step forward in this regard; but the EU could lead on pushing for further change at the international level - for example, in relation to the ongoing revision of ICSID arbitration rules. ${ }^{81}$ Furthermore, we envisage a role for the EU in negotiating new instruments

80 See Clair Gammage, North-South Regional Trade Agreements as Legal Regimes: A Critical Assessment of the EU-SADC Economic Partnership Agreement (Edward Elgar 2017).

${ }_{81}$ See https://icsid.worldbank.org/en/amendments, last accessed 22 November 2018. 
and/or amending existing international instruments that support a business and human rights treaty. ${ }^{82}$

Within the EU internal market trade and investment, the significant role of private actors is acknowledged and regulated, but this is absent in the international legal treatment of trade, investment and finance. The EU might therefore seek to:

- encourage, through multilateral negotiations and FTAs, greater engagement with multinational enterprises and financial institutions, so that they cannot evade sustainability obligations at the expense of states and their citizens, especially since many voluntary mechanisms are failing;

- $\quad$ set up substantive norms for investment treaties (rather than the procedural norms being incrementally established through ICSID and UNCITRAL) which ensure that sustainability concerns commensurate to the capacities of states are placed in such agreements;

- consider diversification in the approach to the content of investment treaties depending on the capacity of partner states, following in this respect the example set by China;

- build capacity within states with weaker bargaining power in terms of civil society institutions, but also social welfare and legal know-how; and

- systematize the engagement of private sector financial actors in blended finance on the international stage (in tandem with its own Sustainable Finance Initiative $)^{83}$ and ensure safeguards to prevent their ability to affect democratic decision-making on public goods and achievement of sustainability objectives.

In this book, it emerges that transparency is of considerable importance, but will not alone deliver accountability. More detailed requirements of state and corporate due diligence are required. The EU must be clear as to the relative hierarchy of certain international instruments - such as the SDGs and other forms of hard and soft law governing human rights, labour standards, and the environment - over the economic entitlements of private market actors. Ethical accountability entails a holistic study of the interaction of trade, investment and finance and we hope that this book contributes to that process.

82 See, for example, the Fourth UN Intergovernmental Working Group session on proposed business and human rights treaty (15-19 October 2018), the records of which are available at www.business-humanrights.org/en/binding-treaty/intergovernmental -working-group-sessions/fourth-un-intergovt-working-group-session-on-proposed -business-human-rights-treaty-15-19-oct-2018, last accessed 22 November 2018.

83 See https://ec.europa.eu/info/business-economy-euro/banking-and-finance/ sustainable-finance_en, last accessed 22 November 2018. 